\title{
Optimization of microwave-assisted extraction process of Hordeum vulgare L. by response surface methodology
}

\author{
Jae-Jun Lee ${ }^{1}$, Dae-Hee Park ${ }^{1}$, Won-Young Lee ${ }^{1,2 *}$ \\ School of Food Science and Technology, Kyoungpook National University, Daegu 41566, Korea \\ Food and Bio-industry Institute, Kyoungpook National University, Daegu 41566, Korea
}

\section{반응표면분석법을 이용한 새싹보리 마이크로웨이브 추출공정의 최적화}

\author{
이재준 ${ }^{1} \cdot$ 박대희 $^{1} \cdot$ 이원영 $1,2 *$ \\ ${ }^{1}$ 경북대학교 식품공학부, ${ }^{2}$ 식품생물산업연구소
}

\begin{abstract}
This study attempted to find optimum extract range of active ingredient for barley sprouts (Hordeum vulgare $\mathbf{L}$.). Extracts from Hordeum vulgare L. were made by microwave extraction method and total polyphenol content (TPC), total flavonoid content (TFC), DPPH radical scavenging activity (DPPH) were measured with extract of Hordeum vulgare L.. Response surface methodology (RSM) was applied to a extraction process, and central composite design (CCD) was also used for this process to examine the optimum condition. Independent variables $\left(X_{n}\right)$ are concentration of ethanol $\left(X_{1}: 0,25,50,75,100 \%\right)$, microwave power $\left(X_{2}: 60,120,180,240,300 \mathrm{~W}\right)$, extraction time $\left(X_{3}\right.$ : $4,8,12,16,20 \mathrm{~min})$. Dependent variables $\left(Y_{n}\right)$ are TPC $\left(Y_{1}\right)$, TFC $\left(Y_{2}\right)$, DPPH radical scavenging $\left(Y_{3}\right)$. It is formed by sixteen conditions to extract. The $R^{2}$ value of dependent variables is ranged from 0.90 to $0.97(p<0.05)$. Experiments values within the optimal range (40\% of ethanol concentration, $120 \mathrm{~W}$ of microwave power, 18 min of extraction time) were $3.74 \mathrm{mg}$ GAE/g (TPC), $3.00 \mathrm{mg} \mathrm{RE} / \mathrm{g}$ (TFC), 35.43\% (DPPH), respectively. Under the optimized conditions, predicted value showed no significant difference comparing with the experimental values.
\end{abstract}

Key words : Hordeum vulgare L., microwave-assisted extraction, response surface methodology, optimized conditions

\section{서 론}

최근 핵가족화의 심화 및 노령인구의 증가로 인해 기존 의 가족구조에서 담당했던 가족구성원 보호 기능이 약화되 고 있으며 이러한 추세와 맞물려 국민 개개인의 건강에 대한 관심이 증대되고 있다. 각종 질환의 예방과 치료에 대한 대중의 의식수준이 높아지고 있으며 건강식품 관련 지식의 증가로 이와 관련한 유기농 건강식품에 관심이 높아 지고 있다 $(1,2)$. 그러한 사례로 최근 새싹채소가 각광받고 있다 $(3,4)$.

*Corresponding author. E-mail : wonyoung@knu.ac.kr Phone : 82-53-950-7763, Fax : 82-53-950-7762

Received 16 October 2017; Revised 19 November 2017; Accepted 21 November 2017.

Copyright (c) The Korean Society of Food Preservation. All rights reserved.
떡잎이 전개되지 않은 상태의 사흘정도 씨앗을 발아시킨 새싹을 새싹채소라 한다. 새싹채소는 싹이 나는 과정에서 탄수화물과 복합단백질이 단당, 아미노산 및 지방산으로 변환되어 소화를 용이하게 한다. 또한, 각종 무기질과 항산 화기능을 가진 비타민 $\mathrm{A}, \mathrm{C}, \mathrm{E}$ 와 다량의 수분, 충분한 양의 섬유질을 내포하고 있다. 브로콜리, 케일, 배추, 양배추, 밀 쌀, 보리싹 등이 대표적인 새싹식물이다 $(5,6)$. 최근 새싹보 리에서 추출된 물질이 알코올성 지방간 해독에 도움을 준다 는 연구결과가 있어 주목을 받고 있다(7).

보리의 어린잎을 새싹보리(Hordeum vulgare L.)라고 명 명하며 생물학적 정의에 따르면 외떡잎식물 벼목 화본과에 속하는 두해살이풀을 지칭한다. 약 $20 \mathrm{~cm}$ 전후의 어린 식물 체로서 새싹보리의 잎과 가루들은 고추장, 엿기름, 보리차 등으로 활용되고 있으며, 보리 국수, 보리 음료 등 다양한 제품에도 이용되고 있다(8). 새싹보리는 외부의 자극으로 부터 스스로를 보호하고 성장하기 위해 높은 생리활성물질 
을 함유한 것으로 알려져 있어 학계의 관심을 받고 있다. 또한 새싹보리가 지질 및 당의 대사작용에 있어 유의한 효능을 보이고 있다는 연구결과들이 보고된 바 있다(9). 이에 따르면 새싹보리는 단백질 함유량이 $35-45 \%$ 에 달하 며 다양한 효소 및 미네랄을 포함하고 있다. 또한 superoxide dismutase, 비타민C, 비타민E, $\beta$-carotene 등의 성분을 함유 하여 이를 섭취할 경우 항산화력 증진에 도움이 되는 것으 로 나타났다(10-12).

새싹보리는 주요 생리활성물질인 헥사코사놀, 사포나린 을 함유하고 있으며 특히 새싹보리의 헥사코사놀은 콜레스 테롤의 생합성을 저해시키는 효과가 있다. 새싹보리를 섭 취한 생물은 간 조직에 축적된 중성지질의 양이 감소하는 결과를 보이고 있다. 사포나린은 플라보노이드 성분으로서 혈중 콜레스테롤과 포도당 농도를 낮추며 지방간을 감소시 키는 효능이 있는 것으로 확인되었다(13,14). 또한 갱년기 여성의 골밀도 제고에 긍정적인 효과가 있다는 연구결과가 있으며(15) 아울러 새싹보리의 루테올린-7-O-글리코시드 (isoorientin-7-O-glucoside)는 바이러스의 확산을 악화시키 는 성분인 뉴라미니데이즈를 저해하는 효과가 탁월한 것으 로 밝혀졌다(16). 이처럼 새싹보리는 각종 생리활성물질과 영양소를 다양하게 함유하고 있으며 건강기능성 식품으로 서의 가치를 높이 평가받고 있다 $(17,18)$.

식품에 함유된 기능성 성분을 추출하기 위한 주요 방법 으로는 압착법(expression), 압력추출법(pressure heating water extraction), 환류 냉각 추출법(reflux extraction), 초임 계 유체추출법(supercritical fluid extraction) 등이 있다(19). 압착법은 조작과 장치가 간단하며 추출물을 안정적으로 추출 할 수 있는 이점이 있지만 수율이 낮은 점이 문제점이 될 수 있으며(20), 압력 추출법은 압착법보다 수율이 좋지만 고온에서 추출하므로 열에 민감한 성분은 소실되기가 쉽다 (21). 환류 냉각 추출법은 식물의 가용성 물질을 안정적으로 추출할 수 있으나 많은 용매가 필요하며 추출 과정에서 많은 시간이 소요되는 단점이 있다(22). 또한, 초임계 유체 추출법은 기능성 물질을 추출하는 속도가 빠르며 용매의 소비량이 적고, 저온에서도 조작할 수 있어 열에 민감한 천연물질의 추출에 유용한 장점이 있지만 많은 비용이 드는 단점을 내포하고 있다 $(23,24)$. 각 추출방법들이 가진 문제 점들을 보완하기 위한 적절한 대안으로 마이크로웨이브추 출(microwave-assisted extraction, MAE)이 주로 사용되고 있다(25). MAE 방식의 추출은 air steam 상의 에너지가 아니 라 시료와 용매가 섞은 혼합물에 집중적으로 마이크로웨이 브 파장을 이용하여 용매와 시료간의 마찰로 열이 발생되는 원리를 활용한다. 이를 통해 시료의 기저에 이르기까지 단 시간에 가열하여 시료 내 유용성분을 효과적으로 추출한다 (26). MAE 방식은 비타민의 파괴나 유용성분의 손실을 줄 일 수 있으며 색소의 파괴도 막을 수 있다. 이렇게 $\mathrm{MAE}$ 방식은 여러 장점이 있기 때문에 식품의 조리, 가공, 살균
및 효소의 불활성화를 위해 다양하게 사용되고 있다(19). 일례로 인삼 추출 시 MAE 방식을 활용할 수 있으며 MAE 방식과 환류 냉각 추출법을 비교하였을 때, 단지 6 분간 추출 한 MAE 방식의 추출물과 8시간가량 환류 냉각 추출법을 이용한 추출물 간의 추출효율이 비슷한 수준으로 나타내는 것으로 보고되고 있다(27).

이러한 내용들을 바탕으로 본 연구에서는 연구대상인 새싹보리의 기능성 성분 추출을 위한 최적의 추출조건을 모색하기 위해 기존의 추출방법들과 비교하여 추출효율 및 수율 측면에서 탁월한 효과가 검증된 MAE 방식을 활용 하고자 한다. 본 연구는 MAE 방식을 기반으로 에탄올을 추출용매로 사용하여 중심합성계획법(central composite design, $\mathrm{CCD}$ )을 이용하여 추출온도와 시간, Micro power가 다른 16 개 추출조건을 설정하였다. 각 조건에 의해 추출된 에탄올 추출물의 기능성 성분 및 라디칼 소거능을 측정한 후 반응표면분석법(response surface methodology, RSM)을 통해 최적의 추출조건을 도출하고자 하였다(28).

\section{재료 및 방법}

\section{실험재료}

실험재료로 사용된 새싹보리(Hordeum vulgare L.)는 강 원도 흥천군 남면에서 재배되었으며, 2017년 2월에 (주맑은 들에서 제조한 열풍 건조 분말을 사용하였다. 시료는 $-18^{\circ} \mathrm{C}$ 인 냉동실에 보관하여 사용하였다.

\section{마이크로웨이브 추출방법 및 장치}

추출방법은 아래의 Fig. 1 과 동일하다. 추출관에 $1 \mathrm{~g}$ 의 새싹보리 시료와 에탄올 용매 $50 \mathrm{~mL}$ 를 넣은 후 조건에 따른 마이크로웨이브 추출을 하였다. 여과지(Whatman filter paper No.1)를 사용하여 여과한 후, $100 \mathrm{~mL}$ 메스플라 스크로 용량을 맞춰 $-5^{\circ} \mathrm{C}$ 냉장고에 보관하여 사용하였다. 마이크로웨이브 추출은 상압형 마이크로웨이브 추출장치 (Soxwave 100, Prolab, Fontenay, France)를 이용하였으며, programmable- power(60-300 W), 시간 제어가 가능하며 환 류냉각관이 장착된 추출장치를 사용하였다.

\section{실험계획}

반응표면분석법(RSM)을 이용하여 최적의 조건을 찾을 때는 반드시 실험 계획법이 필요하다(28). 추출 조건은 중심 합성계획법을 적용하였으며, 용매는 식품에 많이 사용되는 에탄올을 사용하였다. 에탄올 농도 $(0,25,50,75,100 \%)$, 마이크로웨이브 전력 $(60,120,180,240,300 \mathrm{~W})$, 추출시간 $(4,8,12,16,20$ 분 $)$ 을 다르게 하여 예비 실험을 하고, 실험 범위를 설정하여 각각을 5 단계(-2, -1, 0, 1, 2)로 부호화하여 Table 1 과 같이 중심합성계획의 조건을 잡았다. 또한, 임의 
의 16 구를 설정하여 Table 2 와 같이 추출실험을 하였다. 추출공정의 독립변수 $\left(\mathrm{X}_{\mathrm{i}}\right)$ 는 에탄올 농도 $\left(\mathrm{X}_{1}\right)$, 마이크로웨 이브 전력 $\left(\mathrm{X}_{2}\right)$ 와 추출시간 $\left(\mathrm{X}_{3}\right)$ 으로, 종속변수는 $\left(\mathrm{Y}_{\mathrm{n}}\right)$ 는 총 폴리페놀 함량(total polyphenol contents, TPC, $\mathrm{Y}_{1}$ ), 총 플라 보노이드 함량(total flavonoid contents, TFC, $\mathrm{Y}_{2}$ ), DPPH 라 디칼 소거능(DPPH radical scavenging activity, $\mathrm{Y}_{3}$ )로 설정하 였다. 중심합성계획법을 이용하여 나눈 16 개의 임의구간을 설정하여 3 회 측정 후, 평균값의 회귀 분석을 실시하였다 (Table 2). 독립변수와 종속변수에 대한 2차 회귀 모형식은 다음과 같다.

$$
\begin{gathered}
\mathrm{Y}=\mathrm{b}_{0}+\mathrm{b}_{1} \mathrm{X}_{1}+\mathrm{b}_{2} \mathrm{X}_{2}+\mathrm{b}_{3} \mathrm{X}_{3}+\mathrm{b}_{12} \mathrm{X}_{1} \mathrm{X}_{2}+\mathrm{b}_{13} \mathrm{X}_{1} \mathrm{X}_{3}+\mathrm{b}_{23} \mathrm{X}_{2} \mathrm{X}_{3}+\mathrm{b}_{11} \\
\mathrm{X}_{1}^{2}+\mathrm{b}_{22} \mathrm{X}_{2}^{2}+\mathrm{b}_{33} \mathrm{X}_{3}^{2}
\end{gathered}
$$

$\mathrm{Y}$ 는 종속 변수, $\mathrm{X}_{1}, \mathrm{X}_{2}, \mathrm{X}_{3}$ 는 독립 변수, $\mathrm{b}_{0}$ 는 절편, $\mathrm{b}_{\mathrm{n}}$ 은 회귀계수이다. 회귀분석의 결과를 통한 최적조건범위 예측 은 SAS program(Version 9.2, SAS Institute lnc., Cary, NC, USA)을 사용하였으며, mathematica program(Wolfram, Champaign, IL, USA)을 이용하여 4차원 그래프를 통해 최 적의 추출 범위를 분석하였다.

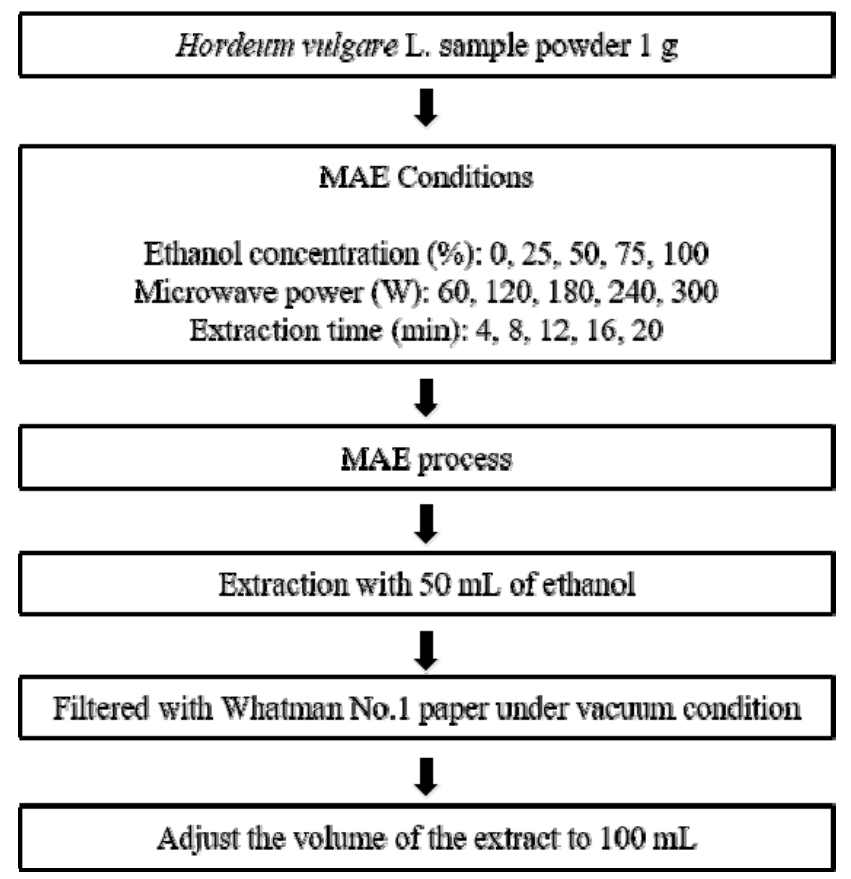

Fig. 1. Scheme for microwave-assisted extraction process for Hordeum vulgare $\mathrm{L}$..

\section{총 폴리페놀 함량 측정}

추출물의 총 폴리페놀 함량은 Folin-Denis법을 변형시켜 비색 정량하였다. 추출한 새싹보리 추출물 $100 \mu \mathrm{L}$ 에 Folin-Ciocalteu reagent $50 \mu \mathrm{L}$ 를 가한 뒤 $2 \% \mathrm{Na}_{2} \mathrm{CO}_{3} 300$ $\mu \mathrm{L}$ 를 넣고 실온에 15 분간 방치했다. 그런 다음 $1 \mathrm{~mL}$ 의 증류수를 넣고 $725 \mathrm{~nm}$ 에서 UV-spectrophotometer(UV2550, Shimazdu Co., Tokyo, Japan)를 이용해 흡광도 값을 측정하였다. 표준물질로는 gallic acid(Sigma-Aldrich)를 검 량선으로 사용하였으며, 그 결과는 $\mathrm{mg} \mathrm{GAE} / \mathrm{g}$, 즉 $1 \mathrm{~g}$ 의 gallic acid에 해당하는 시료의 $\mathrm{mg}$ 으로 나타내었다.

Table 1. The central composite design condition of Hordeum vulgare $\mathrm{L}$. extraction

\begin{tabular}{cccccc}
\hline Extraction condition & -2 & -1 & 0 & 1 & 2 \\
\hline Ethanol concentration $(\%)\left(\mathrm{X}_{1}\right)$ & 0 & 25 & 50 & 75 & 100 \\
Microwave power $(\mathrm{W})\left(\mathrm{X}_{2}\right)$ & 60 & 120 & 180 & 240 & 300 \\
Extraction time $(\mathrm{min})\left(\mathrm{X}_{3}\right)$ & 4 & 8 & 12 & 16 & 20 \\
\hline
\end{tabular}

\section{총 플라보노이드 함량 측정}

추출물의 총 플라보노이드 함량 측정은 추출한 새싹보리 추출물 $70 \mu \mathrm{L}$ 에 증류수 $430 \mu \mathrm{L}$ 를 가한 뒤 $5 \% \mathrm{NaNO}_{2} 50$ $\mu \mathrm{L}$ 를 넣은 다음 $10 \% \mathrm{Al}\left(\mathrm{NO}_{3}\right)_{3} 9 \mathrm{H}_{2} \mathrm{O}$ 를 가한 뒤 상온에서 6분간 놔둔다. 그런 다음 $1 \mathrm{~N} \mathrm{NaOH} 500 \mu \mathrm{L}$ 를 넣어 반응액의 흡광도를 UV-spectrophotometer(UV-2550, Shimazdu Co., Tokyo, Japan)를 이용해 $510 \mathrm{~nm}$ 에서 측정하였다. 표준물질 로는 Rutin(Sigma-Aldrich)을 검량선으로 사용하였으며, 그 결과는 $\mathrm{mg} \mathrm{RE} / \mathrm{g}$, 즉 $1 \mathrm{~g}$ 의 rutin에 해당하는 시료의 $\mathrm{mg}$ 으로 나타내었다.

\section{$\mathrm{DPPH}$ 라디칼 소거능 측정}

추출물의 라디칼 소거능 측정을 위해 $0.0039 \mathrm{~g} \mathrm{DPPH}$ powder에 에탄올 $100 \mathrm{~mL}$ 를 첨가한 후, magnetic stirrer (PC-420D, Corning Co., NY, USA)를 이용하여 $240 \mathrm{rpm}$ 으로 2 시간 동안 용액을 안정화 시키고, $94 \%$ 에탄올로 흡광도가 1.0 에 가까워지도록 희석한 후 사용하였다. 새싹보리 추출 물 $100 \mu \mathrm{L}$ 에 DPPH 용액 $900 \mu \mathrm{L}$ 을 가한 뒤 30분 동안 빛을 차단시키고 반응 후 반응액의 흡광도를 UV-spectrophotometer (UV-2550, Shimazdu Co., Tokyo, Japan)를 사용하여 517 $\mathrm{nm}$ 에서 측정하였다. 이때, control용액은 추출물 $100 \mu \mathrm{L}$ 대신 $94 \%$ 에탄올을 $100 \mu \mathrm{L}$ 를 사용하였다. 측정한 값은 다음 과 같은 식을 이용해 DPPH radical scavenging ability(\%) 값으로 산출하였다.

DPPH radical scavenging activity $(\%)=$

$$
\text { (1- } \left.-\frac{\text { sample absorbance }}{\text { blank absorbance }}\right) \times 100
$$


Table 2. Central composite design matrix for total polyphenol content (TPC), total flavonoid content (TFC), and DPPH radical scavenging activity of Hordeum vulgare L. under microwave-assisted extraction conditions

\begin{tabular}{ccccccc}
\hline No & $\begin{array}{c}\text { Ethanol concentration } \\
(\%)\end{array}$ & $\begin{array}{c}\text { Microwave } \\
(\mathrm{W})\end{array}$ & $\begin{array}{c}\text { power } \\
(\mathrm{min})\end{array}$ & $\begin{array}{c}\text { TPC } \\
(\mathrm{mg} \mathrm{GAE} / \mathrm{g})\end{array}$ & $\begin{array}{c}\text { TFC } \\
(\mathrm{mg} \mathrm{RE} / \mathrm{g})\end{array}$ & $\begin{array}{c}\text { DPPH } \\
(\%)\end{array}$ \\
\hline 1 & 25 & 120 & 8 & $3.17 \pm 0.08$ & $2.50 \pm 0.15$ & $30.14 \pm 0.23$ \\
2 & 75 & 120 & 8 & $3.60 \pm 0.09$ & $4.58 \pm 0.08$ & $34.67 \pm 0.29$ \\
3 & 25 & 120 & 16 & $3.55 \pm 0.08$ & $2.89 \pm 0.22$ & $30.90 \pm 0.48$ \\
4 & 75 & 120 & 16 & $3.87 \pm 0.05$ & $5.74 \pm 0.37$ & $37.21 \pm 0.41$ \\
5 & 25 & 240 & 8 & $3.45 \pm 0.04$ & $2.35 \pm 0.00$ & $29.95 \pm 0.24$ \\
6 & 75 & 240 & 8 & $3.63 \pm 0.04$ & $4.87 \pm 0.08$ & $35.92 \pm 0.48$ \\
7 & 25 & 240 & 16 & $3.64 \pm 0.02$ & $2.40 \pm 0.08$ & $30.02 \pm 0.50$ \\
8 & 75 & 240 & 16 & $3.88 \pm 0.05$ & $9.04 \pm 0.15$ & $38.05 \pm 0.35$ \\
9 & 0 & 180 & 12 & $2.64 \pm 0.03$ & $0.80 \pm 0.08$ & $21.58 \pm 0.41$ \\
10 & 100 & 180 & 12 & $3.3 \pm 0.03$ & $9.33 \pm 0.15$ & $34.44 \pm 0.59$ \\
11 & 50 & 180 & 4 & $3.05 \pm 0.07$ & $2.84 \pm 0.08$ & $30.86 \pm 0.40$ \\
12 & 50 & 180 & 20 & $3.89 \pm 0.05$ & $4.82 \pm 0.29$ & $41.86 \pm 1.47$ \\
13 & 50 & 60 & 12 & $3.34 \pm 0.07$ & $2.69 \pm 0.08$ & $27.05 \pm 0.41$ \\
14 & 50 & 300 & 12 & $3.79 \pm 0.11$ & $4.53 \pm 0.29$ & $3.76 \pm 0.17$ \\
15 & 50 & 180 & 12 & $3.68 \pm 0.10$ & $3.72 \pm 0.17$ & $30.71 \pm 0.57$ \\
16 & 50 & 180 & 12 & $3.67 \pm 0.05$ & $33.11 \pm 0.34$ \\
\hline
\end{tabular}

\section{결과 및 고찰}

\section{총 폴리페놀 함량 측정}

새싹보리를 각각의 조건별로 $\mathrm{MAE}$ 추출하여 총 폴리페 놀 함량을 측정하였다. 4 차원 반응표면그래프는 Fig. 2와

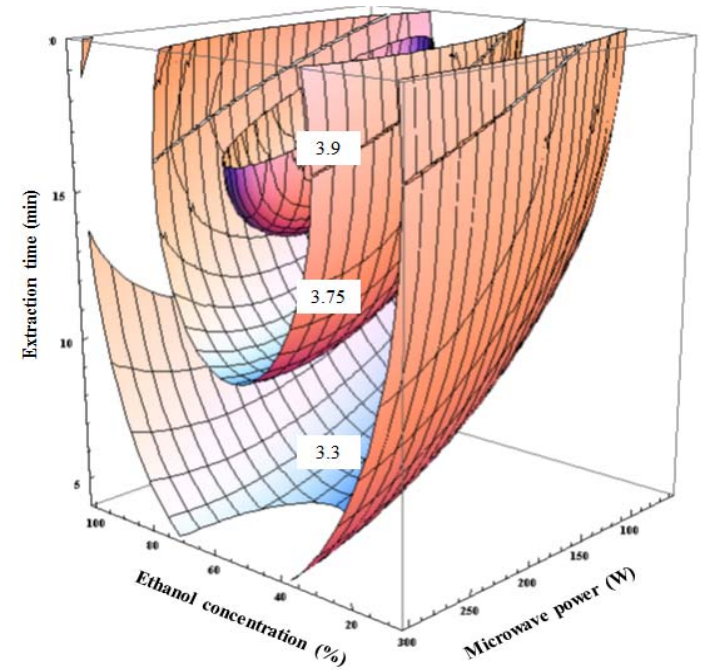

Fig. 2. This is a four-dimensional reaction surface graph of total polyphenol content (TPC) of barley sprouts. extracts at constant values (TPC: $3.3,3.75,3.9 \mathrm{mg} \mathrm{GAE} / \mathrm{g}$ ) as functions of microwave power, ethanol concentration and extraction time in microwaveassisted extraction.
같이 최대점(maximum point)의 형태로 나타났으며, 최대값 은 $3.95 \mathrm{mg} \mathrm{GAE} / \mathrm{g}$ 으로 예측되었다. 에탄올 농도 $(\%)$, 마이 크로웨이브 전력(W), 추출시간(분)에 따른 총 폴리페놀 함 량의 회귀식은 아래와 같다.

$$
\begin{aligned}
\mathrm{Y}_{\mathrm{TPC}}= & 0.753125+0.040125 \mathrm{X}_{1}+0.006802 \mathrm{X}_{2}+0.142969 \mathrm{X}_{3}-0 . \\
& 000282 \mathrm{X}_{1}^{2}-0.000027500 \mathrm{X}_{1} \mathrm{X}_{2}-0.000062500 \mathrm{X}_{1} \mathrm{X}_{3}-0 . \\
& 000007639 \mathrm{X}_{2}^{2}-0.000109 \mathrm{X}_{2} \mathrm{X}_{3}-0.003203 \mathrm{X}_{3}^{2}
\end{aligned}
$$

$\mathrm{R}^{2}$ 값은 0.9028 로 나타났으며, ANOVA 분석 결과 $5 \%$ 이 내의 수준의 유의성을 가졌다(Table 3). 총 폴리페놀 함량의 최적 추출 조건은 에탄올 농도 $58.94 \%$, 마이크로웨이브 전력 $209.04 \mathrm{~W}$, 추출시간은 18.17 분으로 나타났다. 총 폴리 페놀 함량은 에탄올 농도와 추출시간에 따라 영향을 받았으 며, 마이크로웨이브 전력에는 거의 영향을 받지 않았다. 에탄올 농도는 $48-72 \%$ 의 범위에서, 추출시간은 14 분 이상, 마이크로웨이브 전력은 $120 \mathrm{~W}$ 이상의 범위에서 유효했다. Jeong 등(29)의 진피 에탄올 추출조건 최적화 연구에서 총 폴리페놀 함량은 에탄올 농도에 큰 영향을 준다는 유사한 결과를 나타내었다. 또한, Park 등(30)의 댕댕이 추출조건 최적화 연구에서 유사한 에탄올 농도를 보였으나, Lee 등 (31)의 산수유 추출조건 최적화 연구에서는 에탄올 농도가 $30 \%$ 정도의 낮은 농도에서 페놀성 화합물의 함량이 높은 것으로 보고된 바 있어 본 연구와는 상이한 결과를 보였다. 
Table 3. Analysis of variance (ANOVA) results for TPC1), TFC, DPPH of Hordeum vulgare L.

\begin{tabular}{ccccccc}
\hline & $\mathrm{R}^{2}$ & Model & Ethanol concentration $(\%)$ & $\begin{array}{c}\text { Microwave power } \\
(\mathrm{W})\end{array}$ & $\begin{array}{c}\text { Extraction time } \\
(\text { min })\end{array}$ & Stationary point \\
\hline TPC & 0.9028 & $6.19^{* * 2}$ & $7.94^{* *}$ & 1.22 & $4.66^{* *}$ & Maximum \\
TFC & 0.97 & $21.59^{* * *}$ & $42.02^{* * *}$ & $3.66^{*}$ & $6.09^{* *}$ & Saddle \\
DPPH & 0.9063 & $6.45^{* *}$ & $9.02^{* *}$ & 1.17 & 2.80 & Saddle \\
\hline
\end{tabular}

${ }^{1)} \mathrm{TPC}$, total polyphenol content; TFC, total flavonoid content; DPPH, DPPH radical scavenging activity.

2)*** $\mathrm{p}<0.001$, ** $0.001<\mathrm{p}<0.05, * 0.05<\mathrm{p}<0.1$.

Pare 등(32)은 폴리페놀 성분을 추출하는데 마이크로웨이 브 추출이 효과적이라고 하였으며, 이는 마이크로웨이브 에너지로 인하여 시료의 성분이 용매로 추출되기 때문이라 고 하였다.

\section{총 플라보노이드 함량 측정}

새싹보리를 각각의 조건별로 $\mathrm{MAE}$ 추출하여 총 플라보 노이드 함량을 측정하였다. 에탄올 농도 $(\%)$, 마이크로웨이 브 전력(W), 추출시간(분)에 따른 총 플라보노이드 함량의 4차원 그래프는 Fig. 3와 같이 안장점(saddle point)의 형태 로 나타났으며, 회귀식은 아래와 같다.

\section{$\mathrm{Y}_{\mathrm{TFC}}=7.975-0.111925 \mathrm{X}_{1}-0.024156 \mathrm{X}_{2}-0.437656 \mathrm{X}_{3}+0.0005$ $30 \mathrm{X}_{1}^{2}+0.000353 \mathrm{X}_{1} \mathrm{X}_{2}+0.006113 \mathrm{X}_{1} \mathrm{X}_{3}-0.000009028$ $\mathrm{X}_{2}^{2}+0.001391 \mathrm{X}_{2} \mathrm{X}_{3}+0.001406 \mathrm{X}_{3}^{2}$}

$\mathrm{R}^{2}$ 값은 0.97 로 나타났으며, ANOVA 분석 결과 $1 \%$ 이내 의 수준의 유의성을 가졌다(Table 3). 총 플라보노이드의 최적 추출 조건은 에탄올 농도 $52.7 \%$, 마이크로웨이브 전력

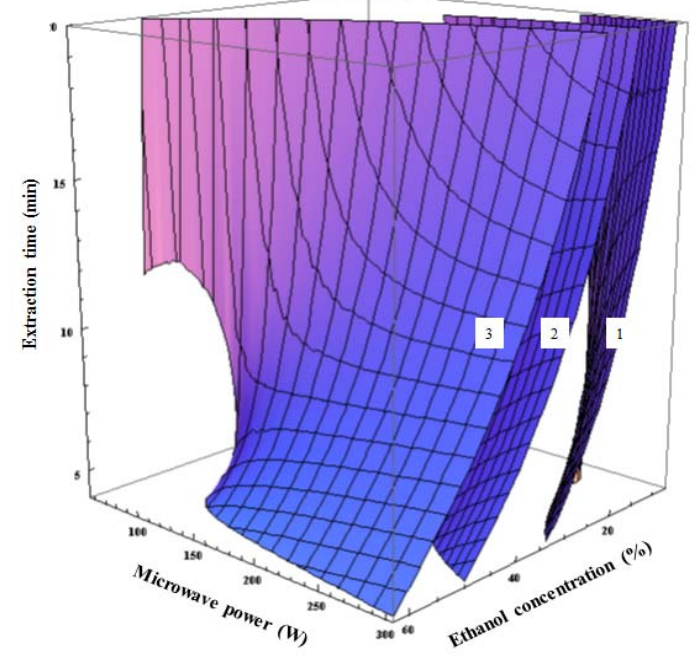

Fig. 3. This is a four-dimensional reaction surface graph of total flavonoid content (TFC) of barley sprouts. extracts at constant values (TFC: $1,2,3 \mathrm{mg} \mathrm{RE} / \mathrm{g}$ ) as functions of microwave power, ethanol concentration and extraction time in microwave-assisted extraction.
$73.03 \mathrm{~W}$, 추출시간은 5 분으로 나타났다. 총 플라보노이드 함량은 에탄올 농도, 추출시간, 마이크로웨이브 전력 순으 로 영향을 많이 받았다. 에탄올 농도는 $22.5-60 \%$ 의 범위에 서, 추출시간은 4 분 이상, 마이크로웨이브 전력 $110 \mathrm{~W}$ 이상 범위에서 유효했다. Min 등(33)의 대추잎 추출조건 최적화 연구에서 총 플라보노이드 함량은 에탄올의 농도에 큰 영향 을 미치는 것에 유사한 결과를 보였다. 반면 Lee 등(34)의 쥐깨풀 추출조건 최적화 연구에서 마이크로웨이브 전력의 의존성이 매우 높게 나타나 상이한 결과 값을 나타내었다.

\section{$\mathrm{DPPH}$ 라디칼 소거능 활성}

새싹보리를 각각의 조건별로 $\mathrm{MAE}$ 추출하여 $\mathrm{DPPH}$ 라디 칼 소거능 활성을 측정하였다. 에탄올 농도(\%), 마이크로웨 이브 전력(W), 추출시간(분)에 따른 $\mathrm{DPPH}$ 의 4차원 반응표 면그래프는 Fig. 4와 같이 안장점(saddle point)의 형태로 나타났으며, 회귀식은 아래와 같다.

\section{$\mathrm{Y}_{\mathrm{DPPH}}=17.060000+0.230600 \mathrm{X}_{1}+0.111396 \mathrm{X}_{2}-0.877188 \mathrm{X}_{3}-$ $0.002092 \mathrm{X}_{1}^{2}+0.000263 \mathrm{X}_{1} \mathrm{X}_{2}+0.004800 \mathrm{X}_{1} \mathrm{X}_{3}-0.000$ $303 \mathrm{X}_{2}^{2}-0.000573 \mathrm{X}_{2} \mathrm{X}_{3}+0.048750 \mathrm{X}_{3}^{2}$}

$\mathrm{R}^{2}$ 값은 0.9063 으로 나타났으며, ANOVA 분석 결과 5\% 이내의 수준의 유의성을 가졌다(Table 3). DPPH 최적의 추출 조건은 에탄올 농도 $75.84 \%$, 마이크로웨이브 전력 $210.79 \mathrm{~W}$, 추출시간은 6.50 분으로 나타났다. $\mathrm{DPPH}$ 는 에탄 올 농도에 영향을 나타냈으며, 마이크로웨이브 전력, 추출 시간은 거의 영향을 주지 않았다. 에탄올 농도는 50-95\%의 범위에서, 추출시간은 6분 이상, 마이크로웨이브 전력 $160-270 \mathrm{~W}$ 범위에서 유효했다. Lee 등(35)의 개똥쑥의 추출 조건 최적화 연구에서 $\mathrm{DPPH}$ 라디칼 소거능 활성의 예측 범위와 최대값 유사하게 나타났다. 반면 $\mathrm{Kim}$ 등(36)의 야관 문의 추출조건 최적화 연구에서 최대값이 $40-60 \%$ 로 낮게 나타나 상이한 결과값을 나타내었다. Eun 등(12), Han 등 (37)의 새싹보리 에탄올 추출물의 DPPH 라디칼 소거능을 비교한 결과, $\mathrm{DPPH}$ radical을 $50 \%$ 저해하는 시료의 농도를 $\mathrm{RC}_{50}$ 값으로 나타내어, $\mathrm{RC}_{50}$ 값이 3 배 정도의 차이가 나타 났다. 이는 재배 지역에 따라 또는 추출 조건에 따라 새싹보 리 추출물의 항산화능 차이가 있다고 보인다. 


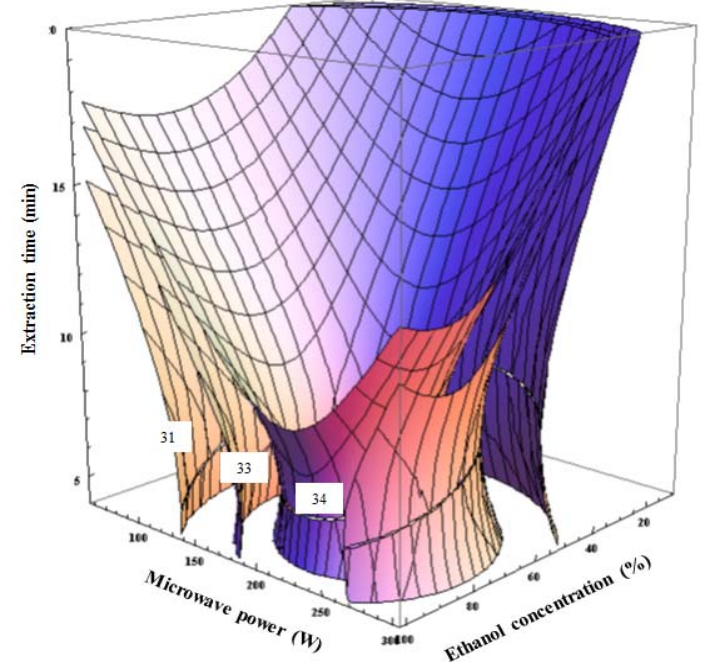

Fig. 4. This is a four-dimensional reaction surface graph of DPPH radical scavenging activity (DPPH) of barley sprouts. extracts at constant values (DPPH: 31, 33, 34\%) as functions of microwave power, ethanol concentration and extraction time in microwaveassisted extraction.

\section{최적 추출 범위 예측}

마이크로웨이브추출을 이용하여 새싹보리의 최적 추출 범위를 예측하기 위해, 총 폴리페놀 함량, 총 플라보노이드 함량, DPPH 라디칼 소거능 활성을 각각의 최적점에 가까운 4차원 그래프를 superimposing하여 최적 범위를 예측하였 다(Fig. 5). 최적 범위는 에탄올 농도는 30-50\%, 마이크로웨 이브 전력은 0-240 W, 추출시간은 $16-20$ 분으로 측정되었 다. 적합 모델식에 대입한 결과 $\mathrm{TPC}$ 는 $3.74 \mathrm{mg} \mathrm{GAE} / \mathrm{g}$, $\mathrm{TFC}$ 는 $3.00 \mathrm{mg} \mathrm{RE} / \mathrm{g}$, DPPH는 $35.43 \%$ 로 나타났다. 예측

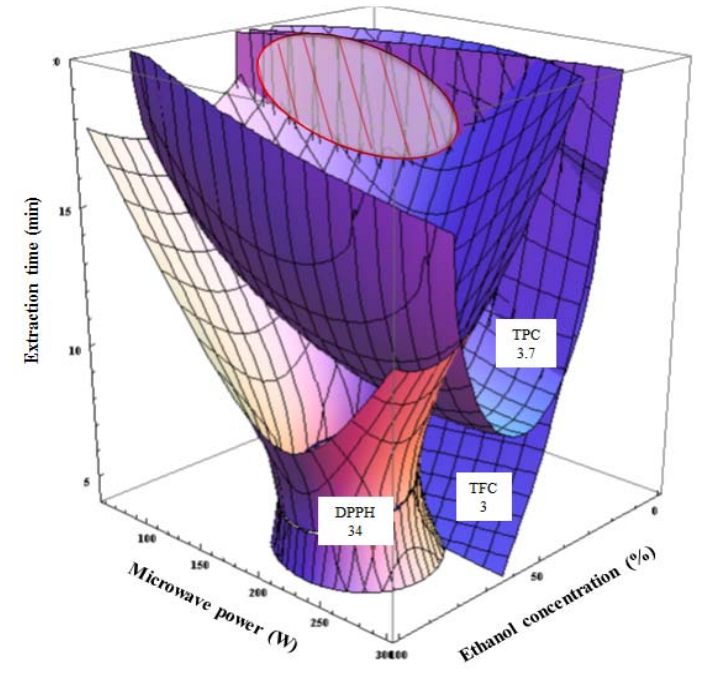

Fig. 5. Superimposed four-dimensional response surfaces for maximized levels of TPC, TFC, DPPH in Hordeum vulgare $\mathrm{L}$. extracts as functions of ethanol concentration, microwave power, and extraction time in microwave-assisted extraction.
결과에 대한 모델식을 검증하기 위해 예측된 최적 범위 내에서 임의의 조건을 선정하였다. 에탄올 농도 $40 \%$, 마이 크로웨이브 전력 $120 \mathrm{~W}$, 추출시간을 18 분으로 임의의 조건 으로 설정하여 확인실험을 진행하였다(Table 4). 그 결과, $\mathrm{TPC}$ 는 $3.38 \mathrm{mg} \mathrm{GAE} / \mathrm{g}$, TFC는 $2.64 \mathrm{mg} \mathrm{RE} / \mathrm{g}$, DPPH는 $37.94 \%$ 로 나타났다. 적합 모델식에 대입한 예측값과 비교 하였을 때, TPC, TFC 함량은 다소 낮게 나타났지만 실험값 은 예측값의 88-107.08\%로 나타나 유효성이 인정되었다 (Table 5).

Table 4. Optimum conditions for total polyphenol content, total flavonoid content, DPPH radical scavenging of Hordeum vulgare L. extracts by superimposing their four-dimensional response surface graphs

\begin{tabular}{ccc}
\hline MAE conditions & Optimal ranges & Predicted optimal condition \\
\hline Ethanol concentration (\%) & $30-50$ & 40 \\
Microwave power (W) & $0-240$ & 120 \\
Extraction time (min) & $16-20$ & 18 \\
\hline
\end{tabular}

Table 5. Comparison between predicted and experimental values for response variable of Hordeum vulgare $\mathbf{L}$. extracts at the given condition within the range of optimal conditions

\begin{tabular}{cccc}
\hline & $\begin{array}{c}\text { Predicted value } \\
(\mathrm{A})\end{array}$ & $\begin{array}{c}\text { Experimental value } \\
(\mathrm{B})\end{array}$ & $\mathrm{B} / \mathrm{A} \times 100(\%)$ \\
\hline $\mathrm{TPC}^{1)}(\mathrm{mg} \mathrm{GAE} / \mathrm{g})$ & 3.74 & 3.38 & 90.37 \\
$\mathrm{TFC}(\mathrm{mg} \mathrm{RE} / \mathrm{g})$ & 3 & 2.64 & 88 \\
$\mathrm{DPPH}(\%)$ & 35.43 & 37.94 & 107.08 \\
\hline
\end{tabular}

${ }^{1)} \mathrm{TPC}$, total polyphenol content; TFC, total flavonoid content; DPPH, DPPH radical scavenging activity.

\section{요 약}

본 연구는 새싹보리를 이용하여 제품 개발에 적용할 수 있도록, 생리활성물질의 최적 추출구간을 설정하는 데에 목적이 있다. 에탄올 농도(0-100\%), 마이크로웨이브 전력 $(60-300 \mathrm{~W})$, 추출시간(4-20분)을 종속 변수로 설정한 후, 빠르고 추출 수율이 좋은 마이크로웨이브추출법을 이용하 여 16 구의 다른 추출 조건을 중심합성계획법에 따라 설정 하여 새싹보리를 추출하였다. 이 후, 추출물의 총 폴리페놀 함량, 총 플라보노이드 함량, DPPH 라디칼 소거능 활성을 측정하였다. 모든 회귀식의 $\mathrm{R}^{2}$ 는 0.9 이상으로 $5 \%$ 수준 이내에서 유의성이 인정되었다. 총 폴리페놀의 최적 추출 조건은 에탄올 농도 $58.94 \%$, 마이크로웨이브 전력 209.04 $\mathrm{W}$, 추출시간은 18.17 분으로 나타났으며, 총 플라보노이드 의 최적 추출 조건은 에탄올 농도 $52.7 \%$, 마이크로웨이브 전력 $73.03 \mathrm{~W}$, 추출시간은 5 분으로 나타났다. $\mathrm{DPPH}$ 라디칼 소거능 활성의 경우, 에탄올 농도 $75.84 \%$, 마이크로웨이브 
전력 $210.79 \mathrm{~W}$, 추출시간 은 6.5 분으로 나타났다. 조건에 따른 TPC, TFC 그리고 DPPH 라디칼 소거능 활성의 예측값 은 각각 $3.84 \mathrm{mg} \mathrm{GAE} / \mathrm{g}, 3.00 \mathrm{mg} \mathrm{RE} / \mathrm{g}$ 그리고 $35.43 \%$ 의 수치를 나타냈다. 최적 범위 내 임의의 점, 즉 에탄올 농도 $40 \%$, 마이크로웨이브 전력 $120 \mathrm{~W}$, 추출시간은 18 분에서 실험값은 $3.38 \mathrm{mg} \mathrm{GAE} / \mathrm{g}, 2.64 \mathrm{mg} \mathrm{RE} / \mathrm{g}$, 그리고 $37.94 \%$ 를 나타냈으며 예측값과 실제 실험값은 유사한 값을 보였다.

\section{References}

1. Jun SY, Kim TH, Hwang SH (2012) The consumption status and preference for sprouts and leafy vegetables. Korean J Food Preserv, 19, 783-791

2. Yoo KM (2015) A opinion on the growth \& revitalization of health functional food market. J Korean Soc Food Sci Nutr, 20, 4-7

3. Lee MY, Shin SL, Chang YD, Lee CH (2009) Environment factors for germination, growing and storage of sprout vegetables of Coreopsis tinctoria Nutt., Saussurea pulchella (Fisch.) Fisch. and Matricaria recutica L.. Korean J Plant Res, 22, 136-144

4. Kim JS, Cho JS, Lee CH (2015) Effect of environmental factors on sprout germination, growth, and storage of six Aster species. Korean J Hortic Sci Technol, 33, 638-646

5. Seo MW (2013) 21. vegetables Sprouts. Hortic Environ Biotechnol, 123-126

6. Kang HM, Kim JG (2013) 4. vegetables Sprouts, Fresh-cutting and processing. Hortic Environ Biotechnol, 555-558

7. Lee YH, Kim JH, Kim SH, Oh JY, Seo WD, Kim KM, Jung JC, Jung YS (2016) Barley sprouts extract attenuates alcoholic fatty liver injury in mice by reducing inflammatory response. Nutrients, 8, 440

8. Kim AR, Lee MY, Lee JJ (2012) Effect of barley leaf ethanol extract on lipid metabolism in rats fed high cholesterol diet. Bull Anim Biotechnol, 4, 15-22

9. Byun AR, Chun HJ, Lee J, Lee SW, Lee HS, Shim KW (2015) Effects of a dietary supplement with barley sprout extract on blood cholesterol metabolism. J Evidance Based Complementary Altern Med, 7

10. Kim DC, Kim DW, Lee SD, In MJ (2006) Preparation of barley leaf powder tea and its quality characteristics. J Korean Soc Food Sci Nutr, 35, 734-737

11. Moon JH (2013) Growth characteristics of barley (Hordeum Vulgare L.) and Wheat (Triticum aestivum L.) sprouts according to light quality of LED. MS Thesis, Kong Ju National University, Korea, p 3-6

12. Eun CS, Hwang EY, Lee SO, Yang SA, Yu MH (2016) Anti-oxidant and anti-inflammatory activities of barley sprout extract. J Life Sci, 26, 537-544

13. Lee JH (2015) Effects of barley sprout and its compounds, hexacosanol and saponarin, on cholesterol and glucose metabolism. Ph D Thesis, Korea University, Korea, $\mathrm{p}$ $159-161$

14. Lee J (2013) Effects of a dietary supplement extracted from barley sprouts on cholesterol metabolism. Ph D Thesis, Ewha Womans University, Korea, p 1-4

15. Bang HR (2017) The effects of barley sprouts(Hordeum Vulgare L.) extract on bone metabolism in ovariectomized rats. Kyung Hee University, MS Thesis, Korea, p 56-65

16. Park MJ (2013) Neuraminidase inhibitory activity of polyphenolic compounds from the barley sprouts (Hordeum Vulgare L.). Pusan National University, MS Thesis, Korea, p 121-122

17. Park SE, Seo SH, Kim EJ, Lee KM, Son HS (2017) Quality characteristics of string cheese prepared with barley sprouts. J Korean Soc Food Sci Nutr, 46, 841-847

18. Lee KS (2015) Analysis of consumer's present use of sprout vegetables and quality characteristics of grain sourdough and barley sprouts. Catholic University, $\mathrm{Ph}$ D Thesis, Korea, p 125-128

19. Joo EY, Kim NW (2008) Polyphenol contents and antioxidant activity of extracts from Angelica dahurica root after different conditions of microwave-assisted extraction. Korean J Food Preserv, 15, 133-138

20. Kwak DH (2001) Determination of food safety in the process for the preparation of edible oil by the analysis of residual organic solvent. Seoul National University of Technology, MS Thesis, Korean, p 1-2

21. Kwon JH, Kim KE, Lee GD (2000) Optimization of microwave-assisted extraction under atmospheric pressure condition for soluble ginseng components. Korean J Food sci Technol, 32, 117-124

22. Lee HJ, Do JR, Kwon JH, Kim HK (2011) Physiological properties of oak mistletoe (Loranthus yadoriki) extracts by microwave extraction condition. Korean J Food Preserv, 18, 72-78

23. Lim SB, Kim SH, Ko YH, Oh CK, Oh MC, Ko YG, Park CS (1995) Extraction yields of Hizikia fusiforme and Aloe vera Linne by supercritical carbon dioxide and antimicrobial activity of their extracts. Korean J Food Sci Technol, 27, 68-73 
24. Lee EJ, Yang SA, Choi HD, Im HG, Whang K, Lee IS (2011) Comparison of gingerols in various fractions and the antioxidant effects of supercritical fluid extracts from ginger. Korean J Food Sci Technol, 43, 469-474

25. Park EJ, Ahn JJ, Kim JS, Kwon JH (2013) Antioxidant activities in freeze-dried and hot air-dried schizandra fruit (Schizandra chinensis Baillon) at different microwaveassisted extraction conditions. Korean J Food Sci Technol, 45, 667-674

26. Lee SY, Shin SR, Kim KS, Kwon JH (2000) Establishment of extraction conditions for effective components from Angelica gigas Nakai using microwave-assisted process. J Korean Soc Food Sci Nutr, 29, 442-447

27. Lee SB, Lee GD, Kwon JH (1999) Optimization of extraction conditions for soluble ginseng components using microwave extraction system under pressure. J Korean Soc Food Sci Nutr, 28, 409-416

28. Bezerra MA, Santelli RE, Oliveira EP, Villar LS, Escaleira LA (2008) Response surface methodology (RSM) as a tool for optimization in analytical chemistry. Talanta, 76, 965-977

29. Jeong JE, Shim SP, Jeong YS, Jung HK, Kim YC, Hong $\mathrm{JH}$ (2011) Optimization of extraction conditions for ethanol extracts from Citrus unshiu peel by response surface methodology. Korean J Food Preserv, 18, 755-763

30. Park DH, Lee JJ, Park JJ, Park SH, Lee WY (2017) Optimization of microwave-assisted extraction process for blue honeysuckle (Lonicera coerulea L.) using response surface methodology. Korean J Food Preserv, 24, 623-630
31. Lee HJ, Do JR, Kwon JH, Kim HK (2012) Optimization of Corni fructus extracts by response surface methodology.

J Korean Soc Food Sci Nutr, 41, 390-395

32. Pare JRJ, Sigouin M, Lapoinate J (1991) Microwaveassisted natural products extraction. US Patent No. 5002784 A

33. Min DL, Lim SW, Ahn JB, Choi YJ (2010) Optimization of ethanol extraction conditions for antioxidants from Zizyphus jujuba Mill. leaves using response surface methodology. Korean J Food Sci Technol, 42, 733-738

34. Lee EJ, Kwon YJ, Noh JE, Lee JE, Lee SH, Kim JK, Kim KS, Choi YH, Kwon JH (2005) Optimization of microwave-assisted process for extraction of effective components from Mosla dianthera M.. Korean J Food Preserv, 12, 617-623

35. Lee SJ, Kang JR, Kim JG, Kang SK, Sung NJ (2013) Establishment of optimum extraction condition for antioxidant activity of Artemisia annua L. by response surface methodology. J Agric Life Sci, 47, 103-113

36. Kim DI, Hong JH (2012) Optimization of ethanol extraction conditions for functional components from Lespedeza cuneata using response surface methodology. Korean J Food Cook Sci, 28, 275-283

37. Han SY (2011) Antioxidative effects of the extract from barley sprout and application of the extracts to an edible oil and fat. MS Thesis, Chonbuk National University, Korea, p 34-36 